\title{
Long-term displacement of intertidal seagrass and mussel beds by expanding large sandy bedforms in the northern Wadden Sea
}

\author{
Tobias Dolch *, Karsten Reise \\ Alfred Wegener Institute for Polar and Marine Research, Wadden Sea Station Sylt, 25992 List, Germany
}

\section{A R T I C L E I N F O}

\section{Article history:}

Received 12 February 2009

Received in revised form 15 October 2009

Accepted 15 October 2009

Available online 25 October 2009

\section{Keywords:}

Large Sandy Bedforms

Intertidal

Hydrodynamics

Mussel Beds

Seagrass Beds

Sea Level Rise

Wadden Sea

\begin{abstract}
A B S T R A C T
On aerial photographs, sandy tidal flats display (1) large sandy bedforms ( $>10 \mathrm{~m}$ long, $>3 \mathrm{~m}$ wide), indicating effects of strong hydrodynamics on sediment relief, and (2) beds of seagrass and mussels, indicating stable sediment conditions. These physical and biogenic structures have been mapped from aerial photographs taken in a back-barrier tidal basin of the North Sea coast at low tide between 1936 and 2005. Fields of large intertidal sandy bedforms show a consistent spatial distribution in the central part of the basin, and have increased in area from 7.2 to $12.8 \mathrm{~km}^{2}$, corresponding now to $10 \%$ of the tidal flats. Areal expansion may be linked to a rise in average high tide level and an increase of the expansion rate from the 1960s to the mid 1990s might be traced back to an increased frequency of storm tides during this period. It is shown that expanding fields of large sandy bedforms have replaced mussel beds in the low tidal zone and displaced seagrass beds in the mid tidal zone. Fields of intertidal large sandy bedforms are expected to expand further with an accelerating rise in sea level, and it is recommended to monitor these physical indicators of sediment instability and disturbance of biogenic benthic structures by analysing aerial photographs.
\end{abstract}

(c) 2009 Elsevier B.V. All rights reserved.

\section{Introduction}

Seagrasses are the dominant vegetation of shallow sandy bottoms in coastal areas around the world (den Hartog, 1970) and they are of high ecological importance for coastal ecosystems (Cunha et al., 2005). Seagrasses are sensitive towards eutrophication, turbidity, strong hydrodynamics (currents and waves), sediment instability, desiccation as well as changes in temperature and salinity (de Jonge and de Jong, 1992; Philippart et al., 1992; Philippart, 1994; Koch, 2001; Schanz and Asmus, 2003). This has resulted in a worldwide decline of seagrass beds often due to human impact as observed since the early 20th century (Hemminga and Duarte, 2000; den Hartog and Phillips, 2001). From 1931 to 1934 , the seagrass pathogen Labyrinthula zosterae caused the so called 'wasting disease' and severely eliminated seagrasses in the Wadden Sea (south-eastern coastal North Sea) (den Hartog, 1987) while eutrophication caused another collapse of beds in the 1970s/1980s (van Katwijk et al., 1999). Today, seagrass beds dominated by Zostera noltii are occurring on about $10 \%$ of the tidal flat area in the northern Wadden Sea, mostly in the upper zone and where sheltered by islands and high sand bars against a rough sea (Reise and Kohlus, 2008).

\footnotetext{
* Corresponding author. Alfred Wegener Institute for Polar and Marine Research, Wadden Sea Station Sylt, Hafenstr. 43, 25992 List, Germany. Tel.: +49 4651956 4216; fax: +494651956200

E-mail address: Tobias.Dolch@awi.de (T. Dolch).
}

Suspension feeding invertebrates often form discrete bioherms at sedimentary coasts, where they live densely packed, stabilising the sediment (Dame et al., 2001). In the Wadden Sea, beds of mussels (Mytilus edulis) generate such bioherms around low tide level, covering $<1 \%$ of the tidal area (Dankers and Zuidema, 1995; Reise and Lackschewitz, 1998). Although mussel beds are rather solid epibenthic structures, they can be heavily damaged by scouring ice floes (Obert and Michaelis, 1991; Strasser et al., 2001) and severe winter storms (Nehls et al., 2002). Mussel fishery may also have an effect. Intertidal mussel beds almost disappeared from the Wadden Sea in the 1980s due to fishery combined with a period of low spatfall (Dankers et al., 1999). A strong decrease in blue mussel bed area, which can be currently observed in the northern Wadden Sea, has been related to the long period of mild winters since 1995/96 which has led to a low recruitment (Nehls et al., 2006). However, since 2001 these declining blue mussel beds have been invaded by Pacific oysters Crassostrea gigas which increase massively in abundance, resulting in mixed beds of mussels and oysters (Diederich et al., 2005; Nehls et al., 2006).

When we surveyed high-resolution aerial photographs taken at low tide since 1936 and analysed the development and spatial pattern of seagrass and mussel beds, we also noticed large bedforms occurring on the tidal flats as they are readily discernible on the aerial photographs. Fields of large sandy bedforms attracted our attention because we observed that they overlap with sites of seagrass and mussel beds, and obviously have increased in area. 
Sandy beach and nearshore environments exhibit a variety of bedforms ranging in scale from small ripple marks $(\mathrm{cm})$, megaripples and large sand waves or subaqueous dunes $(\mathrm{m})$ to very large sand ridges or sorted bedforms (km), all caused by waves and currents interacting with sediment supply, grain size, coastal morphology and depth (i.e., Allen, 1980; Boothroyd, 1985; Ashley, 1990; Anthony and Leth, 2002; Bartholdy et al., 2002; Passchier and Kleinhans, 2005; Diesing et al., 2006; Whitmeyer and FitzGerald, 2008). There are many terms like sand waves or megaripples for large sandy bedforms and a uniform and general definition for these features is still under debate. Therefore, we simply refer to the intertidal sedimentary bedforms we investigated as 'large sandy bedforms'. We here focus on bedforms which have at least a lateral extent of $10 \mathrm{~m}$ and a minimum width of $3 \mathrm{~m}$ and study their distribution in a back-barrier tidal basin of the North Sea. Common among these sandy bedforms is their occurrence in more or less in parallel and in distinct fields. We assume hydrodynamics to have caused their formation.

The Wadden Sea is universally characterized by the largest coherent zone of intertidal mud and sand flats $\left(4700 \mathrm{~km}^{2}\right)$ which are maintained in spite of sea level rise by a natural supply of sediment from the adjacent North Sea bottoms (Bartholdy and Pejrup, 1994; Oost and de Boer, 1994; Flemming and Bartholomä, 1997; CPSL, 2005). However, since the beginning of the last millennium, salt marshes and upper tidal flats have been embanked (Reise, 2005) resulting in a partial loss of fine-grained, nearshore sediment flats and increased hydrodynamics (Flemming and Nyandwi, 1994; Mai and Bartholomä, 2000). In the study area of this survey, the List tidal basin in the northern Wadden Sea, one third of the inner basin has been successively embanked in the course of the last 500 years (Reise, 1998), and in the last century, the tidal flat area decreased from about 66 to $40 \%$ (Fig. 1). The latter is presumably caused by sea level rise which could not be compensated by external sediment supply (Gätje and Reise, 1998). We assume that a spread of large sandy bedforms in the intertidal zone may be a corollary of this long-term development, and suggest that increasing hydrodynamics causes fields of large sandy bedforms to expand. We explore the hypothesis that an expansion of these large bedform fields may interfere with biogenic structures such as mussel and seagrass beds in the intertidal zone of the northern Wadden Sea.

\section{Materials and methods}

\subsection{Study area}

The List tidal basin (Fig. 2 ) is located in the northern Wadden Sea at the German-Danish border $\left(54^{\circ} 50^{\prime}-55^{\circ} 09^{\prime} \mathrm{N}\right.$ and $8^{\circ} 20^{\prime}-8^{\circ} 42^{\prime} \mathrm{E}$ ). Areal size is $5-19 \mathrm{~km}(\mathrm{E}-\mathrm{W})$ by $29 \mathrm{~km}(\mathrm{~N}-\mathrm{S})$ with a total of $406 \mathrm{~km}^{2}$. This tidal basin is an almost closed bay sheltered by the two barrier islands Sylt and Rømø against the swell of the North Sea, and separated from adjacent tidal basins by two causeways connecting the islands with the mainland. A fairly narrow tidal inlet connects the basin with the North Sea. Strong currents with maximum velocities of about $1.3 \mathrm{~ms}^{-1}$ have been measured in the inlet (Backhaus et al., 1998 ) caused by 550 million $\mathrm{m}^{3}$ of water passing to and fro with every tide. Three main channels diverge from the inlet at the flood delta with current velocities of up to $0.6 \mathrm{~ms}^{-1}$, while the current flow on the extensive tidal flats is usually below $0.1 \mathrm{~ms}^{-1}$. Tides are semidiurnal and the mean tidal range is about $2 \mathrm{~m}$ (Backhaus et al., 1998).

\subsection{Large sandy bedforms}

The spatial distribution and areal extent of large sandy bedform fields were analysed on a long-term scale (1936/1945-2003), and the dynamics of individual large sandy bedforms on a medium (19982006) and short-term (May 2005-August 2006) scale. Large sandy bedforms are identified by the following criteria: (a) lighter in colour
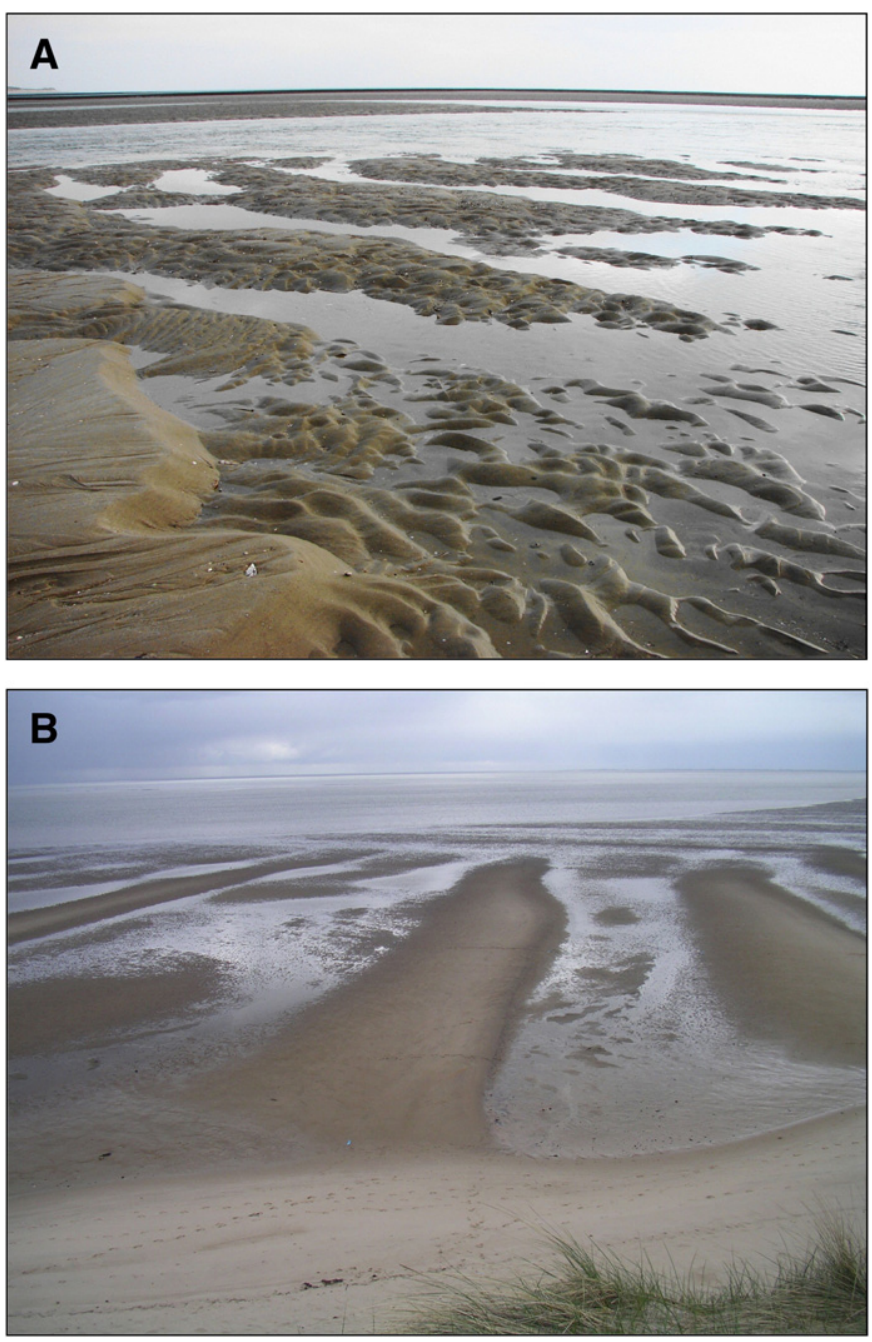

Fig. 1. Intertidal large sandy bedforms at the edge of a tidal channel in Königshafen (A), and perpendicular to the shore at Blidselbucht (B) in the List tidal basin (northern Wadden Sea).

than the surrounding tidal flat sediment, (b) elongate in plain view and (c) elevated above the surrounding tidal flat sediment. All bedforms $>10 \mathrm{~m}$ in lateral extent and $>3 \mathrm{~m}$ in width were included in this study.

Long- and medium-term data were obtained by remote sensing in form of visual analysis of georeferenced, high-resolution aerial photographs, which were taken at low tide. Extensive ground-truth field surveys by GPS measurements were conducted for validation. For the long-term analysis, the position and spatial extent of large sandy bedform fields were recorded by digitising their boundaries on-screen using the Geographic Information System (GIS) ArcGIS 9.2, ArcMap. Boundaries were taken along the outermost occurrence of large sandy bedforms in a field (Fig. 3). Due to constraints in the availability of suitable aerial photographs, the long-term survey was divided into four intervals: $1936 / 1945,1955 / 1968,1989 / 1990$ and 2003. As the aerial photographs are from different sources, they cover different parts of the bay. The four periods resulted from the combination of those photos which are closest together in time in order to cover the entire List tidal basin.

To analyse the medium-term development of individual large sandy bedforms, position and shape were manually digitised from aerial photographs for each year from 1998 to 2006, except for 1999 and 2000 when no photographs were available. Four distinct bedforms were chosen which, during calm weather conditions, would be considered to be associated with a weak current regime 

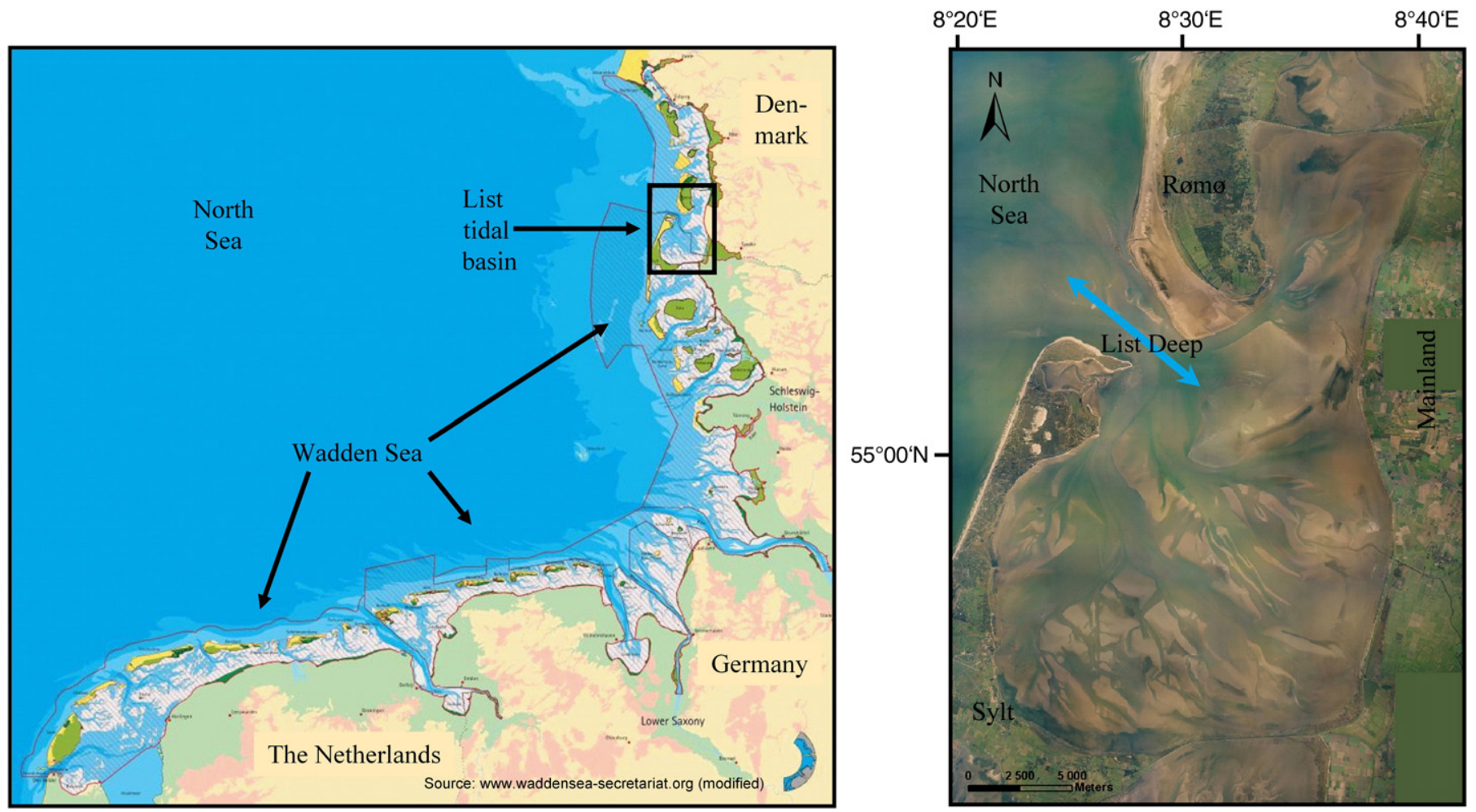

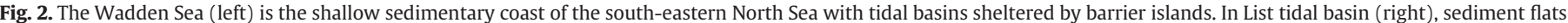
are exposed during low tide. Intertidal seagrass beds are discernible by a dark shadow. The double-headed arrow symbolises the water flow through the tidal inlet.
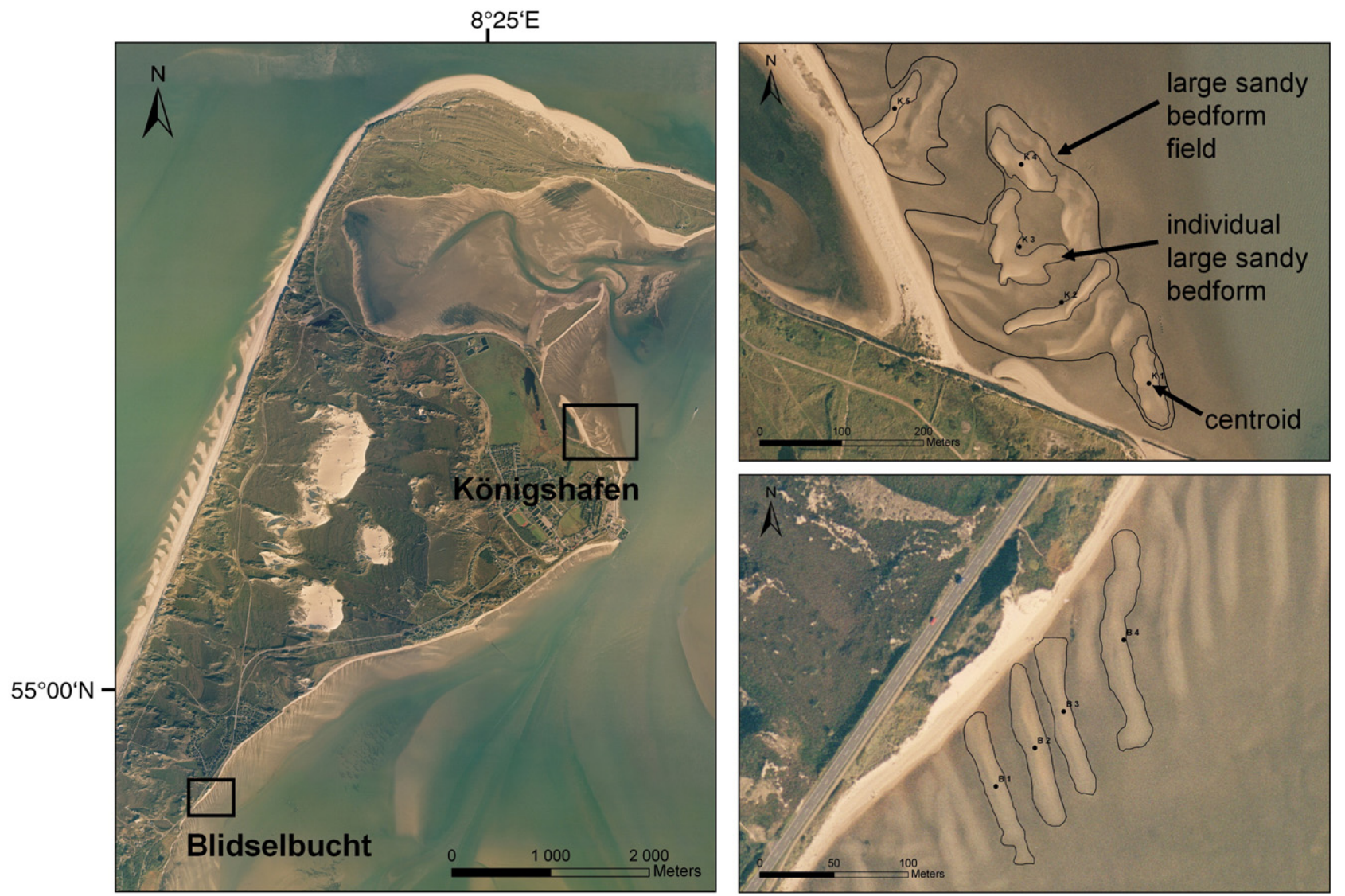

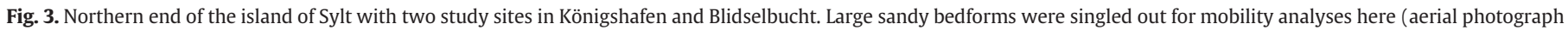
from October 2003). 
(tide-averaged flow velocities: $<0.1 \mathrm{~ms}^{-1}$, Blidselbucht), and five with a moderate current regime $\left(<0.2 \mathrm{~ms}^{-1}\right.$, Königshafen) (Fig. 3).

In GIS the bedforms are presented as polygons and a centroid is the geometric centre of a polygon (Fig. 3). The change in positions of a centroid were taken as a measure for the dynamics of these bedforms as it takes both, changes of shape and changes of position into account. The absolute centroid migration distances from year to year and not the net distances over the entire 8-year interval were recorded. The coordinates of the centroids were calculated in ArcGIS 9.2, ArcMap.

In order to obtain data on short-term dynamics, the same nine large sandy bedforms in Blidselbucht and Königshafen were surveyed in the field with a differential GPS device with a resolution $<1 \mathrm{~m}$. Thirteen field surveys at intervals of 4 to 6 weeks were conducted from May 2005 to August 2006 and centroids were again calculated with GIS (see above).

In May 2005 and March 2006, surface sediment samples $(n=44)$ of 6 to $8 \mathrm{~g}$ were taken for grain size analysis along three parallel profiles running transverse over two large sandy bedform crests and troughs in Blidselbucht. Samples were treated with acetic acid and hydrogen peroxide to destroy non-siliclastic materials. The grain size composition was analysed in the lab with a 'CILAS 1180 Laser particle analyzer'. Resulting data sets were edited and further analysed using 'Gradistat', a grain size distribution and statistics package for the analysis of unconsolidated sediments (Blott and Pye, 2001). Other statistical analyses were conducted with the Statsoft software package STATISTICA 6.0. The statistical significance $(p)$ was determined at the 0.05 (99.95\%) level, the standard deviation being also taken into consideration.

\section{Results}

\subsection{Sediment of crest and troughs of large bedforms}

The large sandy bedforms in Blidselbucht are highly homogeneous, almost symmetric and crests were mainly composed of medium (50$70 \%$ ) and fine sand (20-35\%) with an average grain size of $294.52 \pm$ $20.13 \mu \mathrm{m}(1.83 \pm 0.18 \varphi)$. Troughs also consisted primarily of medium (40-65\%) and fine sand (20-30\%), the average grain size being $260.10 \pm$ $71.67 \mu \mathrm{m}(2.44 \pm 1.33 \varphi)$. Although no significant difference in the grain size composition of the bedforms crests and troughs was detected ( $U$-test, $p=0.25$ ), the sediment of the crests was better sorted. According to the classification by Blott and Pye (2001) the crests are 'moderately well sorted' while the troughs are 'moderately sorted'.

\subsection{Bedform shiftings}

In the aerial surveys, the year-to-year variability of centroid positions of large sandy bedforms in Blidselbucht from 1998 to 2006 was low and without a trend in direction. The mean total distance shifted by the centroids was $16.0 \pm 10.5 \mathrm{~m}$ with a rate of $2.0 \pm 1.3 \mathrm{~m} \mathrm{yr}^{-1}$. In Königshafen, the distance accounted for $33.3 \pm 14.7 \mathrm{~m}$ with a rate of $4.2 \pm 1.8$ myear $^{-1}$. This shifting rate is significantly higher than that in the more sheltered Blidselbucht ( $U$-test, $p=0.027$ ). Again, no trend in direction could be detected over the 8-year period.

In the ground survey from May 2005 to August 2006, the average path length of shifts in position for the four sandy bedform centroids in Blidselbucht was $4.7 \pm 2.2 \mathrm{~m}$ over this 15 -month period, while the five centroids in Königshafen shifted in average $6.8 \pm 4.4 \mathrm{~m}$ (U-test, $p=0.014$ ). No trend in the moving direction was observed at either site. Note that path lengths measured at monthly intervals are significantly higher than those measured annually ( $U$-test, $p=0.029$ and 0.032 for Blidselbucht and Königshafen, respectively).

\subsection{Bedform distribution and extent}

Large sandy bedform populations in List tidal basin can be traced back on high-resolution aerial photographs since 1936/1945. Fields occur along the entire width of the basin (east-west direction) but only over the central part of its length (north-south direction, $55^{\circ} 07.8^{\prime} \mathrm{N}$ to $54^{\circ} 59.1^{\prime} \mathrm{N}$ ). There, large bedform fields are often found in the vicinity to the tidal inlet and main tidal channels (Fig. 4). Populations of large bedforms occur over the entire width of the dissipative, gently sloping tidal flats and often reach up to the slope break of steep reflective beach faces (Fig. 3). In 1936/1945, fields of large bedforms cover an area of $7.185 \mathrm{~km}^{2}$ (Fig. 5), which is $5.4 \%$ of the present intertidal area of List tidal basin. Up to $1955 / 1968$, only minor changes are observed in the spatial distribution, but the existing bedform populations have extended their boundaries to a total cover of $8.116 \mathrm{~km}^{2}$ ( $6.1 \%$ of the intertidal area), corresponding to an expansion rate of $0.044 \mathrm{~km}^{2} \mathrm{year}^{-1}$. Up to 1989/ 1990 the spatial pattern remained and the areal extent of fields expanded to $11.958 \mathrm{~km}^{2}$ (8.9\%). The rate of expansion strongly increased to $0.137 \mathrm{~km}^{2}$ year $^{-1}$ from the 1960 s to 1990 s (Fig. 5). By 2003 the general distribution has extended about $2.7 \mathrm{~km}$ southwards, now occurring from $55^{\circ} 06.4^{\prime} \mathrm{N}$ to $54^{\circ} 57.6^{\prime} \mathrm{N}$ (Fig. 4), covering an area of $12.802 \mathrm{~km}^{2}$ (9.6\%). The mean expansion rate dropped again to $0.062 \mathrm{~km}^{2} \mathrm{yr}^{-1}$ for the last period. Compared to $1936 / 1945$, the areal size of the fields almost doubled (178\%). The average rate of increase over the entire period is $0.09 \mathrm{~km}^{2}$ year $^{-1}$ until 2003.

\subsection{Seagrass and mussel beds}

In addition to the large sandy bedforms, also intertidal seagrass beds and mussel beds are discernible on the aerial photographs. Where seagrass and large sandy bedforms occur together, growth of seagrass tends to be less dense or absent at bedform crests than in the troughs (Figs. 6 and 7). Comparing early and later aerial photographs further shows that in areas where seagrass beds have receded, large sandy bedforms have expanded. This is exemplified in Blidselbucht from 1936 to 2003 (Fig. 6) and in Ostfeuerwatt in Königshafen from 1936 to 2005 (Fig. 7). In Königshafen, in addition to the area shown in Fig. 7, there are three other areas (Westfeuerwatt, Möwenbergwatt and Oddewatt) where seagrass has been displaced by conspicuous large sandy bedforms in recent years. Overall in the List tidal basin, an area of $2.284 \mathrm{~km}^{2}$ formerly (in 1936/1945) covered with seagrass was unvegetated and occupied by large sandy bedforms in 2003.

Furthermore in Königshafen, clusters of mussel beds occurred along low tide line and have been observed to become replaced by large sandy bedforms in the period from 1993 to 2003 (Fig. 8).

\section{Discussion}

\subsection{Large bedforms in the sandy intertidal}

Large bedforms are common features along sandy coasts (Davis, 1985; Bird, 2000). As they usually require sandy sediments and strong hydrodynamics for their formation, they are found where these conditions exist. On a habitat map of the Wadden Sea, large sandy bedforms are indicated on sandy tidal flats at low ( $83 \%$ of symbols) and high elevation (16\%), mostly in the vicinity of tidal inlets (Dijkema et al., 1989). In the List tidal basin large sandy bedforms appear in the sandy central part of the tidal basin. Here, they are confined to distinct fields primarily consisting of populations of mostly parallel large sandy bedforms, while most of the tidal flat area is lacking any discernible large bedforms. Further studies should explore to what extent the spatial pattern can be best explained by strong surf during storm events, by amplified tidal currents when water levels have been raised by onshore winds above normal or by the availability of appropriate sandy sediment. The question arising from this study is: what may have caused the spatial expansion of the large bedforms since 1936/1945 with a somewhat higher rate of spread between the 1960s and 1990s than before and after?

We suggest that an increase of the mean high tide level as well as an increasing frequency in elevated storm tide levels to be the main 

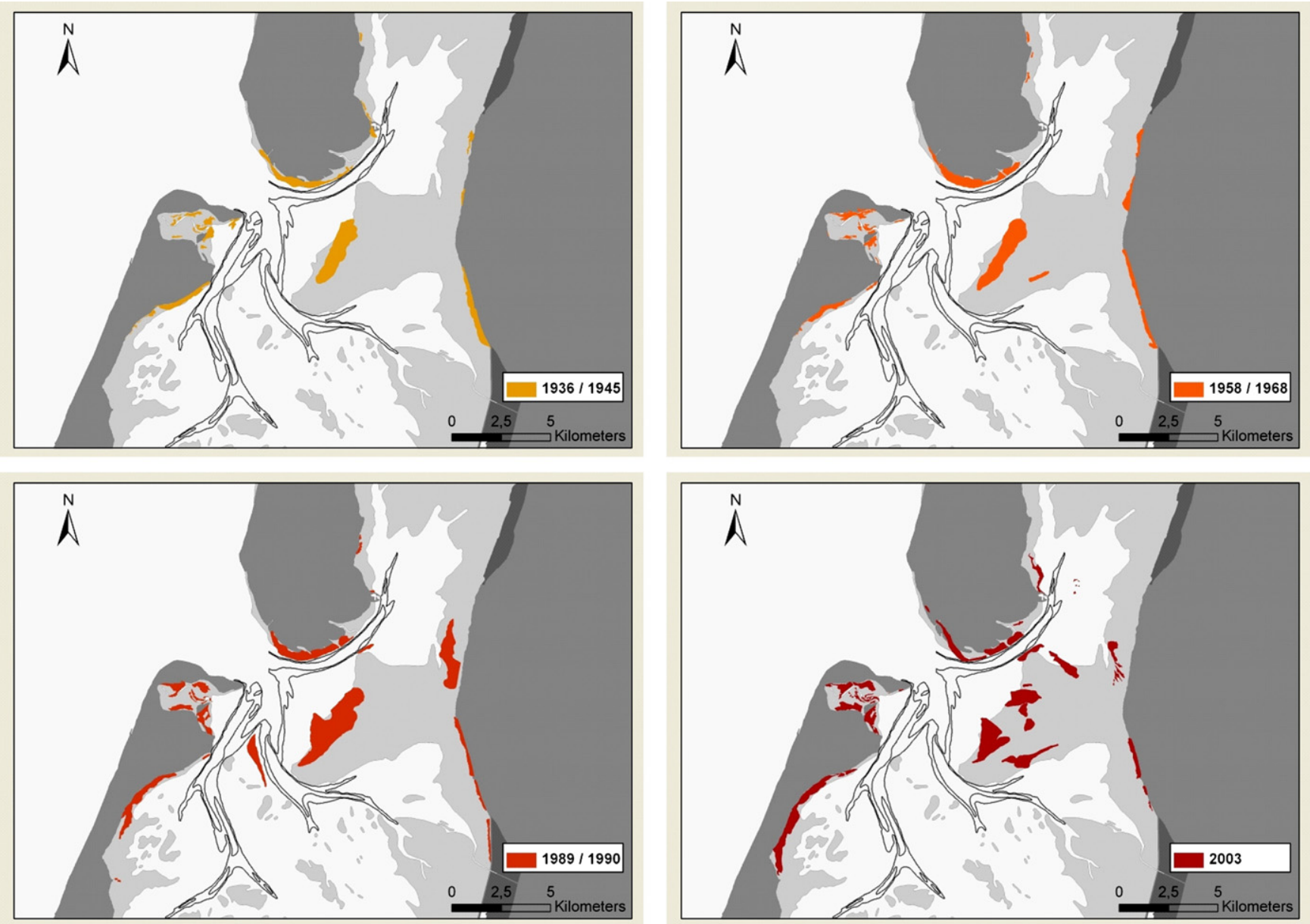

Fig. 4. Development of the spatial distribution and extent of large sandy bedform fields in List tidal basin from 1936/1945 to 2003 .

drivers. At List tidal gauge, the mean low tide level did not vary over the last decades, while the mean high tide level has risen by $17.4 \mathrm{~cm}$ between 1936/45 and 2005, which corresponds to 2.5 mmyear $^{-1}$ in high tide level as well as in tidal range (Fig. 9). This can only in part be explained by global sea level rise. In spite of a high interannual variability, data from the local tide gauge show a strong increase in the duration of elevated water levels by $\geq 1.2$ and $\geq 1.6 \mathrm{~m}$ above mean high tide between 1960 and 1995 (Landesregierung SH, 2001). Further, out of the 20 highest storm surges since 1900, 17 happened between 1960 and 2007. The 3 highest storm tides have been recorded with $3.15 \mathrm{~m}$ in November 1981, $3.04 \mathrm{~m}$ in January 1976 and $2.75 \mathrm{~m}$ in February 1962, measured as tide gauge level above mean

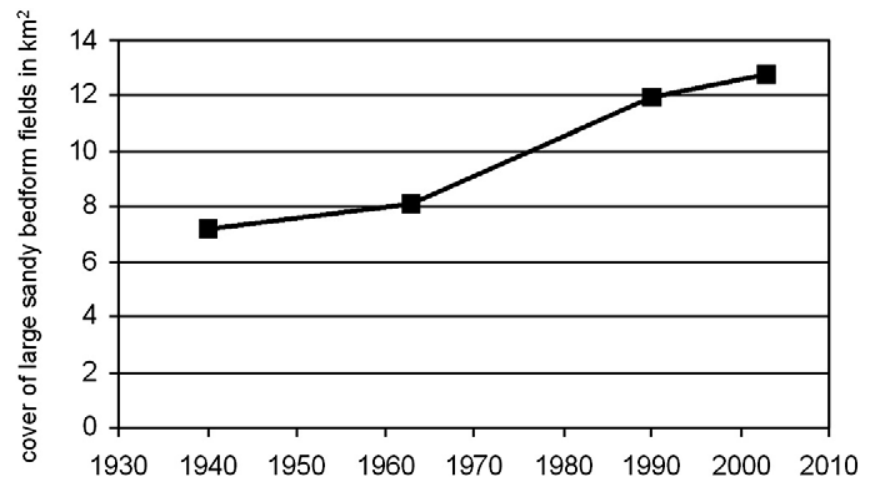

Fig. 5. Development of the total areal size of large sandy bedform fields in List tidal basin from 1936/1945 to 2003. high tide (Landesregierung SH, 2007). During such storm surges, currents on the tidal flats have been found to reach $1.5 \mathrm{~m} \mathrm{~s}^{-1}$ (Landesregierung SH, 2001).

This increase in high tide level and storm tide frequency is a regional phenomenon and thus may have primarily meteorological reasons (Weisse and Plüß, 2006). However, there may also be a local exacerbation by tidal flat embankments and the construction of causeways between the islands and mainland in 1927 and 1948 (Reise, 1998). Over the last 500 years the basin has been constrained by embanking about one third of the area, and the causeways prevent an overflow to the neighbouring tidal basins. Embankments removed finegrained mudflats from the basin by further increasing the hydrodynamic conditions in the tidal basin which comes on top of an overall increase in sea level (Flemming and Nyandwi, 1994; Mai and Bartholomä, 2000). The reduction of the tidal catchment area means less accommodation space for the tidal flow, which results in increased hydrodynamics causing a depletion of fine-grained sediments. For Königshafen in the List tidal basin, a loss of mud flats relative to sand flats since the 1930s has been documented (Dolch and Hass, 2008). Mud depletion and an increasing spatial share of sandflats, where large sandy bedforms can potentially develop, have been observed in the entire Wadden Sea (Flemming and Nyandwi, 1994; Mai and Bartholomä, 2000; Zwarts, 2003; Van Bernem, pers. comm.).

The formation, orientation and migration of large sandy bedforms, like sand waves and megaripples, are not well understood (Gallagher et al., 1998; Gallagher, 2003; Clarke et al., 2008). Necessary preconditions are medium to coarse sand and strong hydrodynamics, however, the underlying processes seem to vary (Allen, 1980; Dalrymple et al., 1978; Shepherd and Hails, 1984; Flemming and Davis, 1994; 

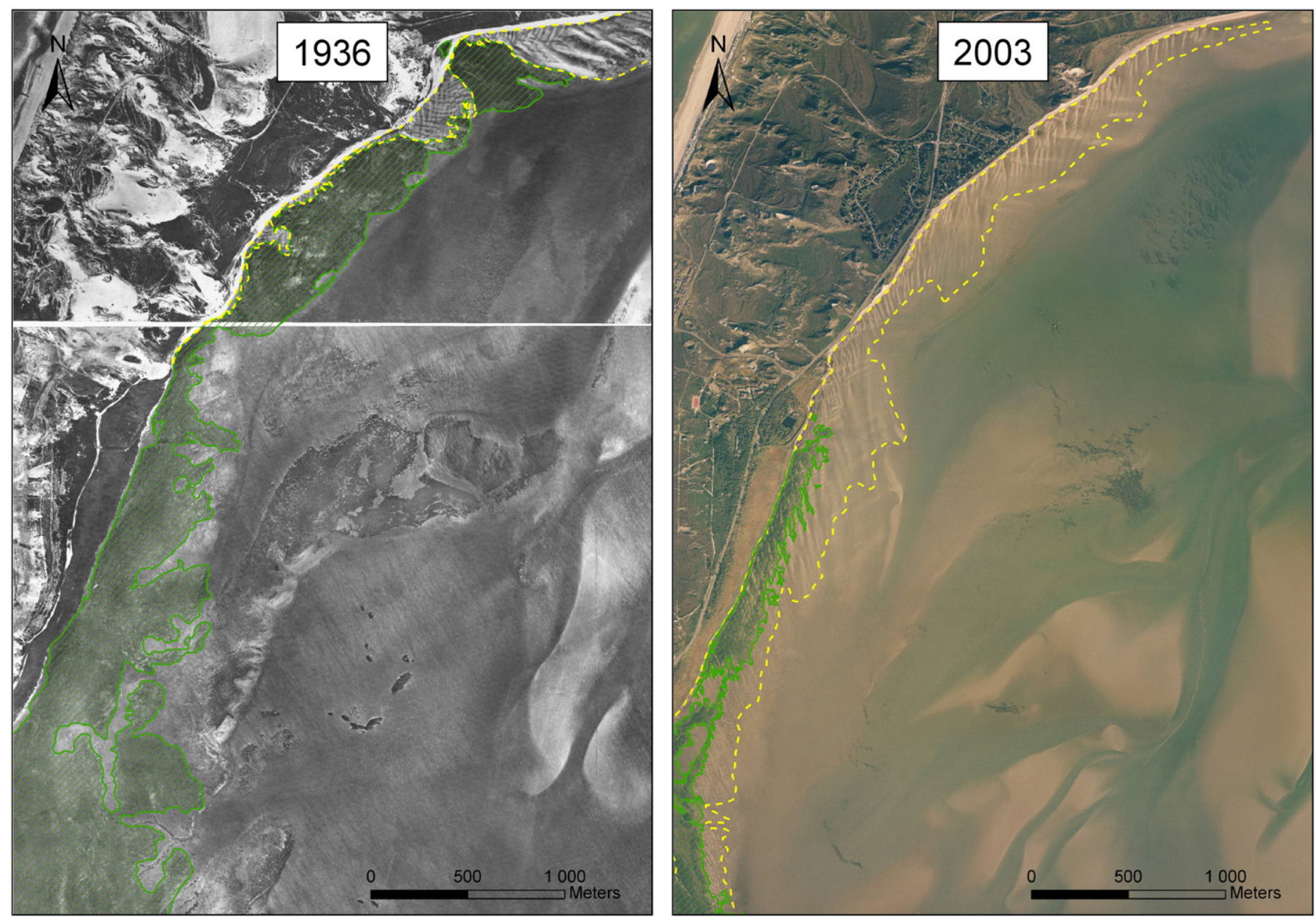

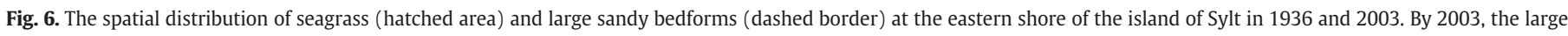
sandy bedforms have intruded into the seagrass bed.

Larcombe and Jago, 1996; Bartholdy et al., 2002; Whitmeyer and FitzGerald, 2008). In the List tidal basin, except for some small fields alongside tidal channels where currents exceed $0.5 \mathrm{~ms}^{-1}$, normal tidal currents are apparently not strong enough to generate the large bedforms visible around mid tide level on the sandy flats. Therefore, we speculate that episodic storm events have created them. This conforms to our assumption that an increase in storm frequency has caused the higher expansion rate of bedform fields between the 1960s and 1990s.

Although sediment supply may play a crucial role in large bedform formation, our grain size analysis does not indicate that an external source of sediment is necessary for the bedforms we observed. They seem to arise by bedload transport within sites. However, at the two investigated sites, we surveyed over several years, the large sandy bedforms merely moved back and forth. From observations at the ground we know that also the height and shape tend to vary between years as well as between months. Thus, large sandy bedforms may be taken as indicators for sediment mobility rather than stability.

We here suggest that areal expansion of large intertidal bedforms, readily recognisable on aerial photographs, constitutes a convenient indicator for a general development of increasing hydrodynamics and sandiness as well as sediment instability in the Wadden Sea and other coastal regions.

\subsection{Interactions between physical and biotic bedforms}

In the Wadden Sea, intertidal mussel and seagrass beds are mainly found in areas sheltered against westerly storm surges or areas which otherwise provide a firm substrate where mussels can adhere or seagrass can be well rooted (Nehls and Thiel, 1993; Reise and Kohlus, 2008). In the List tidal basin, mussel beds occur around low tide level and comprise $0.8 \%$ of the intertidal area while seagrass beds are primarily located in the upper to mid intertidal zone and cover $19.8 \%$ (Reise and Lackschewitz, 1998). Seagrass is sensitive to strong hydrodynamics (de Jonge et al., 1996; Fonseca and Bell, 1998; Schanz and Asmus, 2003) as well as to sediment instability as it cannot withstand erosion or being buried by sedimentation (Philippart et al., 1992; Marbà et al., 1994; Cabaço and Santos, 2007; Daniell et al., 2008). Our long-term remote sensing data reveal that areas formerly inhabited by seagrass are now invaded by large sandy bedforms.

The question arises if large sandy bedforms colonise areas where seagrass has vanished or if they actually cause the disappearance of seagrass. Fig. 7 shows that large sandy bedforms appear before the seagrass is gone. Furthermore, it is unlikely that seagrass could be able to prevent large sandy bedforms from intruding. Although the intertidal Z. noltii is perennial and may stabilise sediment (Widdows et al., 2008), the leaves are shed in autumn and thus during winter the seagrass sites appear to be bare. Winter is the season when almost all storms happen to occur which could contribute to large sandy bedform development or enhancement. Thus, we assume that the generation of large sandy bedforms by storm tides is the immediate cause for seagrass decline and not a consequence of receding seagrass. According to our observations on bedform positions over time, the mechanism is most likely to be that large sandy bedforms are intermittently shifting back and forth by which they cause sediment instability which harms the seagrass. We found no evidence that large 

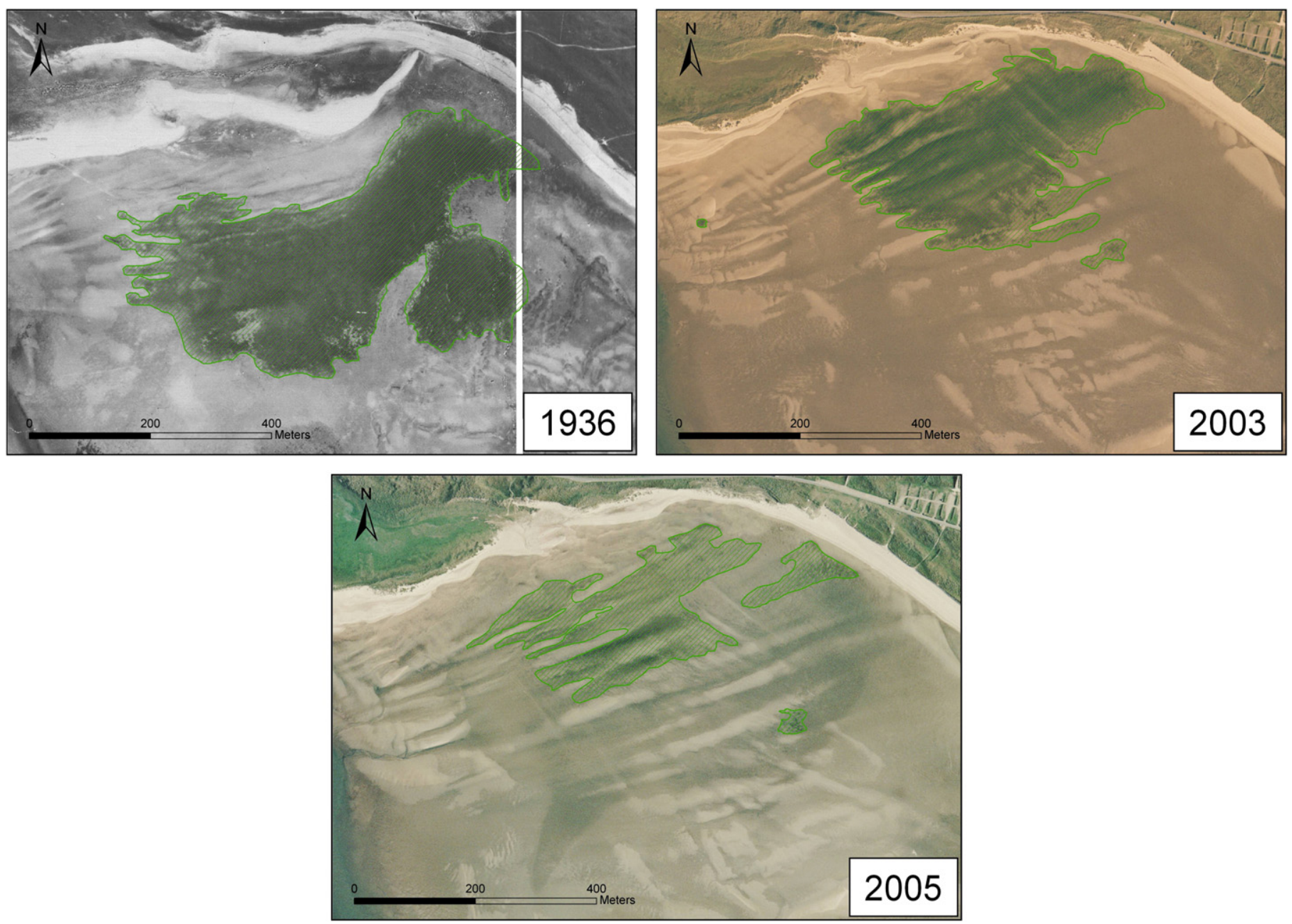

Fig. 7. Development of large sandy bedforms and a seagrass bed (hatched area) in Königshafen, shown for 1936,2003 and 2005.

sandy bedforms migrate continuously across seagrass beds. Parallel large sandy bedforms are close enough to each other to gradually affect also the seagrass growing in the troughs by moving back and forth until all seagrasses are gone due to burial effects. However, because this process may be ultimately driven by episodic storm events, there need not be a deterministic decline. The seagrass bed shown in Fig. 7 actually has slightly recovered in 2007 and 2008 (own ground surveys).

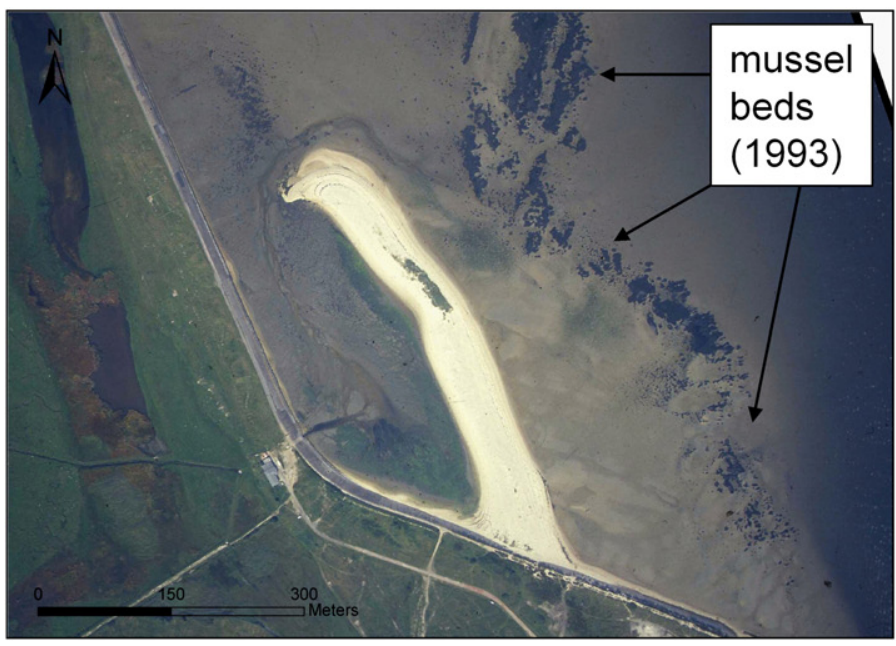

In spite of this, the future for seagrass on sandy tidal flats in the Wadden Sea is dim. An accelerating sea level rise is one of the most certain consequences of global warming (Zhang et al., 2004). A rise of 0.5 to $1.4 \mathrm{~m}$ above the 1990 level by 2100 has been projected by Rahmstorf (2007). Storm tides - whether increasing in the next decades or not (Woth et al., 2006) - would come on top of a higher mean water level. This may give rise to large sandy bedforms displacing seagrass from sandy tidal areas. Such a process may be

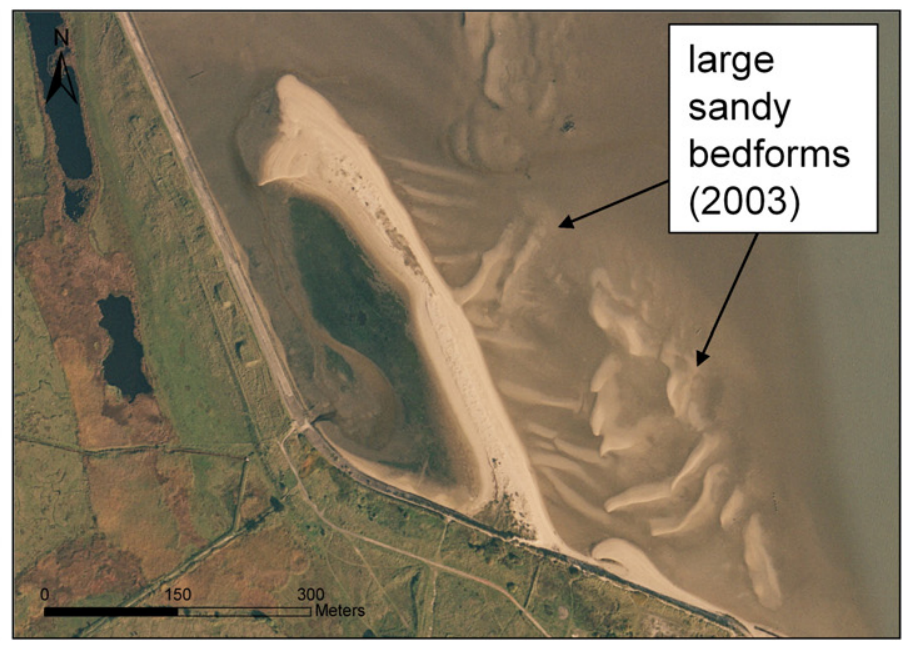

Fig. 8. South-eastern Königshafen with a sandy hook and mussel beds in 1993 as well as conspicuous large sandy bedforms in 2003. 


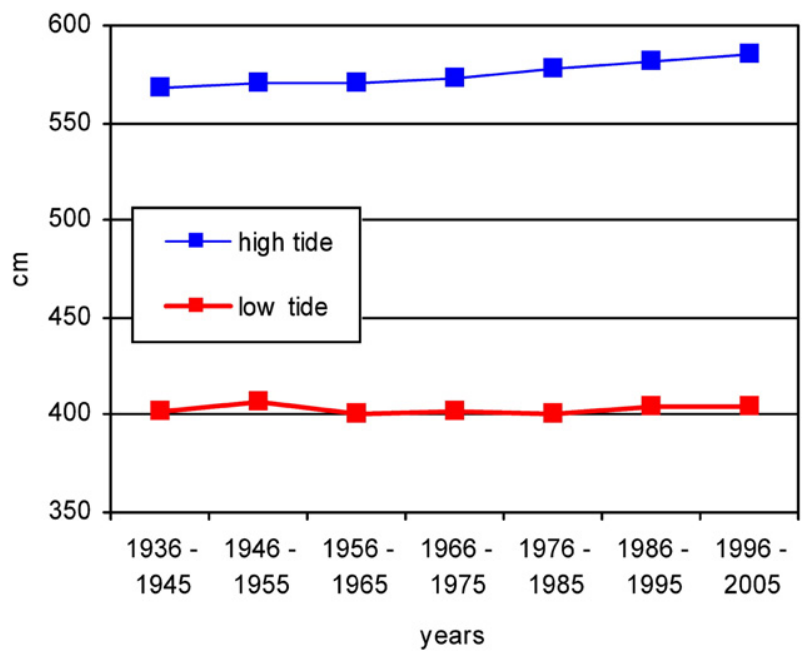

Fig. 9. Development of high and low tide level shown in 10-year averages at the tidal gauge List over the last seven decades.

(data source: Waterways and Shipping Board Tönning, Germany).

already underway in the List tidal basin since the 1960s and the situation of seagrass is likely to exacerbate unless storm frequencies decline again. The Wadden Sea may undergo a further loss of mudflats and an increasing spatial share of sandflats because of the depletion of fine-grained sediments caused by increased hydrodynamics (Flemming and Nyandwi, 1994; Mai and Bartholomä, 2000). A general coarsening of sediments implies that areas where large sandy bedforms may develop are increasing while retreat areas for seagrass are declining.

Mussel beds may be less prone to invasion of large sandy bedforms because mussels form resistant, compact aggregates, capable of stabilising the sediment surface year-round. Thus, large sandy bedforms may not be able to develop within dense clusters of mussel beds. Nevertheless, as shown in Fig. 8, an apparent replacement has happened in Königshafen. At a site of former mussel beds a field of irregularly shaped and relatively mobile large sandy bedforms have established. In this case, however, the former mussel beds have been scoured off by ice in the severe winter 1995/96 (Strasser et al., 2001). The large sandy bedforms have developed subsequently after the mussels were already gone. In this case large sandy bedforms replace mussel beds while seagrass beds tend to be displaced. However, large sandy bedforms may have prevented a renewed settlement of mussels as they are no features where young mussels can attach to. More than a decade after the mussel beds have been wiped out by scouring ice at that site, mussels still have not managed a comeback.

However, mussels are not anymore the dominant epibenthic habitat engineers in the List tidal basin as they were of old. Pacific oysters C. gigas have taken over (Diederich et al., 2005; Nehls et al., 2006). Just north of the large sandy bedform field shown in Fig. 8, an extensive oyster bed has established in the 2000s, particularly since a very heavy spatfall in 2006 (own observations). At that site, there was sufficient shell material and some remnants of mussel beds for oyster larvae to attach to and a large coherent oyster bed has developed. Oysters are heavier, much larger than mussels and are cemented to each other. This may prevent the development of new large sandy bedforms more effectively than the former clusters of mussel beds. However, similar to mussels, oysters will not be able to settle within a field of established large sandy bedforms.

Expanding fields of large sandy bedforms generally seem to have the potential to dis- or replace biogenic epibenthic structures such as beds of seagrass and suspension feeders. Other benthos which is inhibited by sediment instability is also expected to decline where large sandy bedforms develop anew. This development may entail a decline in biomass production with implications for the nursery function and foraging ground potential of the Wadden Sea for staging coastal birds. We thus recommend the monitoring of large sandy bedforms in the intertidal zone via analysis of aerial photographs in order to evaluate the impact of hydrodynamic developments.

\section{Conclusions}

1. Fields of large sandy bedforms have expanded significantly on sandy tidal flats in the northern Wadden Sea over the last 7 decades.

2. If sea level rise accelerates as projected for the 21st century, level sandy flats may become increasingly occupied by fields of large sandy bedforms.

3. Within such intertidal fields, large sandy bedforms move back and forth, thereby causing unstable sediment conditions.

4. We discovered that intertidal beds of seagrass fade away when large sandy bedforms develop within them.

5. A field of large sandy bedforms has developed where a cluster of blue mussel beds had gone, and presumably prevents reestablishment of mussels.

6. Readily discernible large sandy bedforms on low tide aerial photographs of intertidal flats are suggested as a handy indicator for potentially advancing sediment instability and its ecological implications.

\section{Acknowledgements}

We thank Christian Buschbaum and two anonymous reviewers for their very helpful comments on the manuscript. Eric Fee kindly improved the language. Christian Hass (AWI), the Regional Office of the Schleswig-Holstein Wadden Sea National Park, Tönning (NPA), the Regional State Office for the Rural Areas, Husum (ALR), the Sønderjyllands Amt, Tønder/Denmark (SJA) and the GKSS are gratefully acknowledged for providing aerial photographs. Thanks also to the Waterways and Shipping Board in Tönning for providing long-term data from the gauge List.

\section{References}

Allen, J.R.L., 1980. Sand waves: a model of origin and internal structure. Sediment. Geol. 26, 281-328.

Anthony, D., Leth, J.O., 2002. Large-scale bedforms, sediment distribution and sand mobility in the eastern North Sea off the Danish west coast. Mar. Geol. 182, 247-263.

Ashley, G.M., 1990. Classification of large-scale subaqueous bedforms: a new look at an old problem. SEPM bedforms and bedding structures. J. Sediment. Petrol. 60 (1) $160-172$.

Backhaus, J., Hartke, D., Hübner, U., Lohse, H., Müller, A., 1998. Hydrographie und Klima im Lister Tidebecken. In: Gätje, C., Reise, K. (Eds.), Ökosystem Wattenmeer. Springer, Berlin, pp. 39-54.

Bartholdy, J., Pejrup, M., 1994. Holocene evolution of the Danish Wadden Sea. Senckenb. Marit. 24, 187-209.

Bartholdy, J., Bartholomae, A., Flemming, B.W., 2002. Grain-size control of large compound flow-transverse bedforms in a tidal inlet of the Danish Wadden Sea. Mar. Geol. 188, 391-413.

Bird, E.C.F. (Ed.), 2000. Coastal Geomorphology - An Introduction. Wiley, Chichester, p. 322. Blott, S.J., Pye, K., 2001. Gradistat: A grain size distribution and statistics package for the analysis of unconsolidated sediments. Earth Surf. Process. Landf. 26, 1237-1248.

Boothroyd, J.C., 1985. Tidal inlets and tidal deltas, In: DavisJr. Jr., R.A. (Ed.), Coastal Sedimentary Environments, 2nd ed. Springer, New York.

Cabaço, S., Santos, R., 2007. Effects of burial and erosion on the seagrass Zostera noltii. J. Exp. Mar. Biol. Ecol. 340, 204-212.

Clarke, L.B., Werner, B.T., Okihiro, M., 2008. Surf zone megaripple orientation: measurements and models. J. Geophys. Res. 113, 13 C03018.

CPSL, 2005. Coastal protection and sea level rise. Solutions for sustainable coastal protection in the Wadden Sea region. Wadden Sea Ecosyst. 21, 1-47.

Cunha, A.H., Santos, R.P., Gaspar, A.P., Bairros, M.F., 2005. Seagrass landscape-scale changes in response to disturbance created by the dynamics of barrier islands: a case study from Ria Formosa (Southern Portugal). Estuar. Coast. Shelf Sci. 64 636-644.

Dalrymple, R.W., Knight, R.J., Lambiase, J.J., 1978. Bedforms and their hydraulic stability relationships in a tidal environment, Bay of Fundy, Canada. Nature 275, 100-104. 
Dame, R.F., Bushek, D., Prins, T.C., 2001. Benthic suspension feeders as determinants of ecosystem structure and function in shallow coastal waters. In: Reise, K. (Ed.), Ecological Comparisons of Sedimentary Shores. Springer, Berlin, pp. 11-37.

Daniell, J.J., Harris, P.T., Hughes, M.G., Hemer, M., Heap, A., 2008. The potential impact of bedform migration on seagrass communities in Torres Strait, northern Australia. Cont. Shelf Res. 28 (16), 2188-2202.

Dankers, N., Zuidema, D.R., 1995. The role of the mussel (Mytilus edulis) and mussel culture in the Dutch Wadden Sea. Estuaries 18, 71-80.

Dankers, N., Brinkman, A.G., Meijboom, A., Zegers, J., 1999. Recovery of intertidal mussel beds in the Wadden Sea after large-scale destruction. J. Shellfish Res. 18 (2), 713.

DavisJr. Jr., R.A. (Ed.), 1985. Coastal sedimentary environments. Springer, New York, p. 716

den Hartog, C. (Ed.), 1970. The Sea-grasses of the World. North-Holland Publ Comp, Amsterdam, London.

den Hartog, C., 1987. Wasting disease and other dynamic phenomena in Zostera beds. Aquat. Bot. 27, 3-14.

den Hartog, C., Phillips, R.C., 2001. Common structures and properties of seagrass beds fringing the coasts of the world. In: Reise, K. (Ed.), Ecological Comparisons of Sedimentary Shores. Springer, Berlin, pp. 195-212.

de Jonge, V.N., de Jong, D.J., 1992. Role of tide, light and fisheries in the decline of Zostera Marina L. in the Dutch Wadden Sea. Publ. Ser. Neth. Inst. Sea Res. 20, 161-176.

de Jonge, V.N., de Jong, D.J., van den Bergs, J., 1996. Reintroduction of eelgrass (Zostera marina) in the Dutch Wadden Sea; a review of research and suggestions for management measures. J. Coast. Conserv. 2, 149-158.

Diederich, S., Nehls, G., van Beusekom, J.E.E., Reise, K., 2005. Introduced Pacific oysters (Crassostrea gigas) in the northern Wadden Sea: invasion accelerated by warm summers? Helgol. Mar. Res. 59, 97-106.

Diesing, M., Kubicki, A., Winter, C., Schwarzer, K., 2006. Decadal scale stability of sorted bedforms, German Bight, southeastern North Sea. Cont. Shelf Res. 26, 902-916.

Dijkema, K.S., van Tienen, G., van Beek, J.G., 1989. Habitats of The Netherlands, German and Danish Wadden Sea 1:100, 000. Research Institute for Nature Management Texel and Veth Foundation, Leiden. $30 \mathrm{pp}$.

Dolch, T., Hass, H.C., 2008. Long-term changes of intertidal and subtidal sediment compositions in a tidal basin in the northern Wadden Sea (SE North Sea). Helgol. Mar. Res. 62, 3-11.

Flemming, B.W., Bartholomä, A., 1997. Response of the Wadden Sea to a rising sea level: a predictive empirical model. Dtsch. Hydrogr. Z. 49, 343-353.

Flemming, B.W., Davis Jr., R.A., 1994. Holocene evolution, morphodynamics and sedimentology of the Spiekeroog barrier island system (southern North Sea). Senckenb. Marit. 24 (1-6), 117-155.

Flemming, B.W., Nyandwi, N., 1994. Land reclamation as a cause of fine-grained sediment depletion in backbarrier tidal flats (southern North Sea). Neth. J. Aquat. Ecol. 28, 299-307.

Fonseca, M.S., Bell, S.S., 1998. Influence of physical settings on seagrass landscapes near Beaufort, North Carolina, USA. Mar. Ecol. Prog. Ser. 171, 109-121.

Gallagher, E.L., 2003. A note on megaripples in the surf zone: evidence for their relation to steady flow dunes. Mar. Geol. 193, 171-176.

Gallagher, E.L., Elgar, S., Thornton, E.B., 1998. Megaripple migration in a natural surf zone. Nature 394, 165-168.

Gätje, C., Reise, K., 1998. Ökosystem Wattenmeer. Austausch-, Transport- und Stoffumwandlungsprozesse. Springer, Berlin, p. 435.

Hemminga, M.A., Duarte, C.M. (Eds.), 2000. Seagrass Ecology. Cambridge University Press, Cambridge.

Koch, E.W., 2001. Beyond light: physical, geological, and geochemical parameters as possible submersed aquatic vegetation habitat requirements. Estuaries 24 (1), $1-17$.

Landesregierung SH (Ministerium für ländliche Räume, Landesplanung, Landwirtschaft und Tourismus des Landes Schleswig-Holstein), 2001. Generalplan Küstenschutz Integriertes Küstenschutzmanagement in Schleswig-Holstein, Kiel, pp. 76.

Landesregierung SH (Landesbetrieb für Küstenschutz, Nationalpark und Meeresschutz Schleswig-Holstein), 2007. Morphologischer Zustand Westküste Sylt 2007, Bericht 01/2008, www.lkn.schleswig-holstein.de, pp. 79.

Larcombe, P., Jago, C.F., 1996. The morphological dynamics of intertidal megaripples in the Mawddach Estuary, North Wales, and the implications for palaeoflow reconstructions. Sedimentology 43, 541-559.
Mai, S., Bartholomä, A., 2000. The missing mud flats of the Wadden Sea: a reconstruction of sediments and accommodation space lost in the wake of land reclamation. In: Flemming, B.W., Delafontaine, M.T., Liebezeit, G. (Eds.), Muddy Coast Dynamics and Resource Management. Elsevier, Amsterdam, pp. 257-272.

Marbà, N., Cebrián, J., Enríquez, S., Duarte, C.M., 1994. Migration of large-scale subaqueous bedforms measured with seagrasses (Cymodocea nodosa) as tracers. Limnol. Oceanogr. 39 (1), 126-133.

Nehls, G., Thiel, M., 1993. Large-scale distribution patterns of the mussel Mytilus edulis in the Wadden Sea of Schleswig-Holstein: do storms structure the ecosystem? Neth. J. Sea Res. 31, 181-187.

Nehls, G., Diederichs, A., Stoddard, P., 2002. Miesmuschelmonitoring im Nationalpark Schleswig-Holsteinisches Wattenmeer 2001. Bericht an das Landesamt für den Nationalpark Schleswig-Holsteinisches Wattenmeer. Hockensbüll.

Nehls, G., Diederich, S., Thieltges, D.W., Strasser, M., 2006. Wadden Sea mussel beds invaded by oysters and slipper limpets: competition and climate control? Helgol. Mar. Res. 60, 135-143.

Obert, B., Michaelis, H., 1991. History and ecology of the mussel beds (Mytilus edulis L.) in the catchment area of a Wadden Sea tidal inlet. In: Elliott, M. Ducrotoy, J.-P. (Eds.), Estuaries and Coasts. Spatial and Temporal Intercomparisons. Olsen \& Olsen, pp. 185-194

Oost, A.P., de Boer, P.L., 1994. Sedimentology and development of barrier islands, ebbtidal deltas, inlets and backbarrier areas of the Dutch Wadden Sea. Senckenb. Marit. 24, 65-115.

Passchier, S., Kleinhans, M.G., 2005. Observations of sand waves, megaripples, and hummocks in the Dutch coastal area and their relation to currents and combined flow conditions. J. Geophys. Res. 110, 15 F04S15.

Philippart, C.J.M., 1994. Interactions between Arenicola marina and Zostera noltii on a tidal flat in the Wadden Sea. Mar. Ecol. Prog. Ser. 111, 251-257.

Philippart, C.J.M., Dijkema, K.S., van der Meer, J., 1992. Wadden Sea seagrasses: where and why? Publ. Ser. Neth. Inst. Sea Res. 20, 177-191.

Rahmstorf, S., 2007. A semi-empirical approach to projecting future sea-level rise. Science $315,368-370$.

Reise, K., 1998. Coastal change in a tidal backbarrier basin of the Northern Wadden Sea: are tidal flats fading away? Senckenb. Marit. 29, 121-127.

Reise, K., 2005. Coast of change: habitat loss and transformations in the Wadden Sea. Helgol. Mar. Res. 59, 9-21.

Reise, K., Kohlus, J., 2008. Seagrass recovery in the Northern Wadden Sea? Helgol. Mar. Res. 62, 77-84

Reise, K., Lackschewitz, D., 1998. Benthos des Wattenmeeres zwischen Sylt und Rømø. In: Gätje, C., Reise, K. (Eds.), Ökosystem Wattenmeer. Springer, Berlin, pp. 55-64.

Schanz, A., Asmus, H., 2003. Impact of hydrodynamics on development and morphology of intertidal seagrasses in the Wadden Sea. Mar. Ecol. Prog. Ser. 261, 123-134.

Shepherd, S.A., Hails, J.R., 1984. The dynamics of a megaripple field in Northern Spencer Gulf, South Australia. Mar. Geol. 61, 249-263.

Strasser, M., Reinwald, T., Reise, K., 2001. Differential effects of the severe winter of 1995/96 on the intertidal bivalves Mytilus edulis, Cerastoderma edule and Mya arenaria in the Northern Wadden Sea. Helgol. Mar. Res. 55, 190-197.

van Katwijk, M.M., Schmitz, G.H.W., Gasselink, A.P., van Avesaath, P.H., 1999. Effects of salinity and nutrient load and their interaction on Zostera marina. Mar. Ecol. Prog. Ser. 190, 155-165.

Weisse, R., Plüß, A., 2006. Strom-related sea level variations along the North Sea coast as simulated by a high-resolution model 1958-2002. Ocean Dyn. 56, 16-25.

Whitmeyer, S.J., FitzGerald, D.M., 2008. Episodic dynamics of a sand wave field. Mar. Geol. 252, 24-37.

Widdows, J., Pope, N.D., Brinsley, M.D., Asmus, H., Asmus, R.M., 2008. Effects of seagrass beds (Zostera noltii and Z. marina) on near-bed hydrodynamics and sediment resuspension. Mar. Ecol. Prog. Ser. 358, 125-136.

Woth, K., Weisse, R., von Storch, H., 2006. Climate change and North Sea storm surge extremes: an ensemble study of storm surge extremes expected in a changed climate projected by four different regional climate models. Ocean Dyn. 56, 3-15.

Zhang, K., Douglas, B.C., Leatherman, St.P., 2004. Global warming and coastal erosion. Clim. Change 64 (1-2), 41-58.

Zwarts, L., 2003. Bodemgesteldheid en mechanische kokkelvisserij in de Waddenzee. RIZA Rapport. RIZA Lelystad. 